\title{
Physico-Chemical Properties of Antiseptics in Surgery: What is not Taken into Account in Treating Long-Term Non-Healing Wounds
}

Vishwanath Pradeep

Bodduluri -

Department of Pharmaceutical

Sciences

Konstantin G. Gurevich -

Dr. Sci. (Med.), Prof.,

Department of Healthy

Lifestyle,

orcid.org/0000-0002-7603-6064

Alexander L. Urakov -

Dr. Sci. (Med.), Prof.,

Department of General and

Clinical Pharmacology,

orcid.org/0000-0002-9829-9463
Vishwanath Pradeep Bodduluri', Konstantin G. Gurevich², Alexander L. Urakov ${ }^{*}$

${ }^{1}$ Kravi Pharmaceutical Institute, Hyderabad, India

${ }^{2}$ A.I. Yevdokimov Moscow State University of Medicine and Dentistry, Moscow, Russian Federation

${ }^{3}$ Izhevsk State Medical Academy, Izhevsk, Russian Federation

*Correspondence to: Alexander L. Urakov, e-mail: urakoval@live.ru

\section{Abstract}

The treatment of long-term non-healing wounds in the conditions of purulent surgery departments, widely uses solutions of chemotherapeutic and antiseptic agents. The most common are the solutions of 3-6\% hydrogen peroxide and solutions of 2-10 \% sodium chloride. As a rule, solutions of these drugs are used to treat non-healing, particularly, purulent wounds, bedsores and trophic ulcers. Therefore, solutions are injected into the wound area repeatedly in the form of course therapy. The findings show that the mechanism of action of these drugs and the effect of treating long-term non-healing wounds is largely determined by such physical and chemical factors of their local interaction as concentration of the main ingredients, osmotic, alkaline activity and local temperature. The findings point out the leading role of the local temperature and the dependence of the local effect on the concentration. They describe the essence of the innovative method of treatment.

Keywords: purulent surgery, trophic ulcers, antiseptics, sanitization of purulent wounds, temperature, hydrogen peroxide, sodium chloride

For citation: Bodduluri V.P., Gurevich K.G., Urakov A.L. Physico-Chemical Properties of Antiseptics in Surgery: What is not Taken into Account in Treating Long-Term Non-Healing Wounds. Creative Surgery and Oncology. 2021;11(3):256259. https://doi.org/10.24060/2076-3093-2021-11-3-256-259 


\section{Физико-химические свойства антисептических}

\section{средств: что мы не учитываем в лечении длительно незаживающих ран}

\author{
V.P. Bodduluri', К.Г. Гуревич², А.Л. Ураков ${ }^{3, *}$ \\ ${ }^{1}$ Фармацевтический институт Крави, Индия, Хайдарабад \\ ${ }^{2}$ Московский государственный медико-стоматологический университет имени А.И. Евдокимова, Россия, Москва \\ ${ }^{3}$ Ижевская государственная медицинская академия, Россия, Удмуртская Республика, Ижевск \\ * Контакты: Ураков Александр Ливиевич, e-mail: urakoval@live.ru
}

\section{Аннотация}

При лечении длительно незаживающих ран в условиях отделений гнойной хирургии широко используются растворы химиотерапевтических и антисептических средств. До сих пор распространено применение растворов 3-6 \% перекиси водорода и 2-10 \% натрия хлорида. Как правило, растворы этих лекарственных средств используют для лечения незаживающих, в частности гнойных, ран, пролежней и трофических язв. Поэтому растворы вводят в область ран многократно в виде курсовой терапии. Показано, что механизм действия указанных лекарственных средств и эффект лечения длительно незаживающих ран во многом определяется такими физико-химическими факторами их локального взаимодействия, как концентрация основных ингредиентов, осмотическая, щелочная активность и локальная температура. Указывается ведущая роль локальной температуры и зависимость локального эффекта от концентрации. Описывается сущность инновационного способа лечения.

Ключевые слова: гнойная хирургия, трофические язвы, антисептические средства, санирование гнойных ран, температура, перекись водорода, натрий хлорид

Для цитирования: Bodduluri V.P., Gurevich K.G., Urakov A.L. Physico-Chemical Properties of Antiseptics in Surgery: What is not Taken into Account in Treating Long-Term Non-Healing Wounds. Creative Surgery and Oncology. 2021;11(3):256-259. https://doi.org/10.24060/2076-3093-2021-11-3-256-259
Bodduluri Vishwanath Pradeep -

кафедра фармачевтических наук

Гуревич Константин Георгиевич Ә.м.н., профессор, кафедра здорового образа жизни, orcid.org/0000-0002-7603-6064

Ураков Александр Ливиевич -

д.м.н., профессор, кафедра общей и клинической фармакологии, orcid.org/0000-0002-9829-9463 
The number of patients with purulent and long-term nonhealing wounds and the effectiveness of their treatment with the use of existing medical standards and medicines remain the same $[1,2]$. Therefore, the issue of developing new medicines and innovative methods of treating purulent diseases remains very relevant [3].

Methods to treat long-term non-healing wounds are still traditionally based on their detersion and drainage using solutions of chemotherapeutic agents, for example, sulfonamide preparations and antibiotics, and hypertonic solutions of $2-10 \%$ sodium chloride in combination with solutions of 3-6 \% hydrogen peroxide [4].

The disadvantage of these methods of treatment is that the local use of solutions of chemotherapeutic and antiseptic agents without taking into account the concentration of the main ingredients, alkaline, osmotic and temperature activity does not provide high efficiency and safety [5]. The fact is that an increase in the concentration of ingredients leads to an inhibition of the division process in the regenerating tissues of the wound surface, as well as to an increase in the local irritant effect up to its transformation into a cauterizing effect [6]. In particular, the application of a bandage moistened with a solution of salt and / or carbohydrate with an excessively high concentration has a denaturing effect on the granulation tissue. On the other hand, the absence of moderate alkalinity in the purulent masses within the $\mathrm{pH}$ of 8.4 and the local temperature within $+37-42{ }^{\circ} \mathrm{C}$ does not contribute to the dissolution of thick pus and the healing of purulent wounds $[7,8]$.

In this regard, we appeal to surgeons to pay attention to the great role of these physico-chemical factors in local interaction in treating long-term non-healing wounds. We are convinced that to optimize their treatment can be achieved by cleaning the wound surface by irrigation with a solution of $3 \%$ hydrogen peroxide at a $\mathrm{pH}$ of 8.4 and a temperature of $+37^{\circ} \mathrm{C}$.

The fact is that these physico-chemical factors of local interaction of drug solutions with thick and viscous purulent masses have been used by mankind since ancient times all over the world. This was achieved by treating long-term non-healing purulent wounds and trophic ulcers with the help of certain physio-procedures. However, until the last decades, humanity did not have scientific evidence proving the presence of these interaction factors and scientific explanations of a certain role of a certain physico-chemical factor. Therefore, official medicine has lost the ancient ways and means of treating purulent wounds. The scientific justification of these traditions appeared only at the beginning of the 20th century [5].

In our opinion, an example of a scientifically justified return to the traditional treatment of purulent wounds is the invention of "A method for treating long-term nonhealing wounds" [9]. The essence of this method, which includes a course of daily irrigation of the wound surface with a solution of $3 \%$ hydrogen peroxide at a temperature of $+37^{\circ} \mathrm{C}$, is to heat the wound area with infrared radiation until persistent thermal hyperemia in the wound surface, but not exceeding the temperature of $+42^{\circ} \mathrm{C}$ and heating during 15 minutes, to use $2-4 \%$ sodium chloride as a hypertonic solution at a temperature of $+42{ }^{\circ} \mathrm{C}$ and to subsequently apply a warming element to the dressing, maintaining the temperature of the wound area at $+37^{\circ} \mathrm{C}$ during the entire period until the next thermal medicinal procedure.

Pretreatment of the wound with a warm solution of $3 \%$ hydrogen peroxide accelerates the removal of purulentnecrotic masses and the healing process, since this drug does not have a cauterizing effect and does not destroy granulation, but it accelerates metabolism in the granulating tissue. Short-term (lasting up to 15 minutes) infrared irradiation, for example, using a Sollux lamp, and warming the wound area up to $+42^{\circ} \mathrm{C}$ helps to accelerate the healing process, since it modulates such symptoms of inflammation as hyperthermia and hyperemia, revives and accelerates the process of true inflammation, the occurrence of granulation, but irreversible thermal damage is excluded. In turn, applying a solution of $2-4 \%$ sodium chloride to the wound with a bandage at a temperature of $+42{ }^{\circ} \mathrm{C}$ maintains an optimal hyperthermic regime, which allows even more intensively accelerating the healing process. Warming the wound area and maintaining the temperature therein within $+37^{\circ} \mathrm{C}$ is also intented to accelerate the healing process, since otherwise the wound area is often cooled under normal conditions.

The method can be implemented as follows. The wound surface is cleaned of purulent-necrotic masses by irrigation with a solution of $3 \%$ hydrogen peroxide heated to $+37^{\circ} \mathrm{C}$. Then the temperature of the wound surface is measured, for example, using an infrared scanner, infrared radiation from the Sollux lamp is directed to the wound surface, making sure its warmth reaches a state of hyperemia and a temperature of $+42{ }^{\circ} \mathrm{C}$. At the same time, the heating duration should not exceed 15 minutes. If hyperemia does not happen, the procedure is stopped after 15 minutes. After reaching a state of persistent hyperemia, the wound is covered with a cotton-gauze swab moistened with a solution of $2 \%$ sodium chloride at a temperature of $+42^{\circ} \mathrm{C}$, and with a warming element, such as a heating pad in order to maintain the temperature regime in the future at the level of $+37^{\circ} \mathrm{C}$ continuously until the next similar procedure.

\section{Information about conflict of interest.}

The authors declare no conflict of interest.

\section{Information about funding.}

This work is not funded.

\section{References}

1 Tretyakov A.A., Petrov S.V., Neverov A.N., Shchtinin A.F. Treatment of purulent wounds. Novosti Khirurgii. 2015; 23(6):680-7 (In Russ.) DOI: 10.18484/2305-0047.2015.6.680

2 Letzelter J., Hill J.B., Hacquebord J. An overview of skin antiseptics used in orthopaedic surgery procedures. J Am Acad Orthop Surg. 2019;27(16):599-606. DOI: 10.5435/JAAOS-D-18-00105

3 Wade R.G., Burr N.E., McCauley G., Bourke G., Efthimiou O. The comparative efficacy of chlorhexidine gluconate and povidoneiodine antiseptics for the prevention of infection in clean surgery: a systematic review and network meta-analysis. Ann Surg. 2020 Sep 1. DOI: 10.1097/SLA.0000000000004076. Epub ahead of print. 
4 Hirsch T., Seipp H.M., Jacobsen F., Goertz O., Steinau H.U., Steinstraesser L. Antiseptics in surgery. Eplasty. 2010;10:e39. PMID 20526354

5 Urakov A.L. Pus solvents as new drugs with unique physical and chemical property. Reviews on Clinical Pharmacology and Drug Therapy. 2019;17(4):89-95 (In Russ.). DOI: 10.17816/ RCF17489-95

6 Urakov A.L., Urakova N.A., Alies Yu.M., Nikityuk D.B., Gurevich K.G., Lovtsova L.V., et al. Physico-chemical activity of solutions as an integral part of the mechanism of local drug effect. Pharmacy. 2019;68(6):42-9 (In Russ.). DOI: 10.29296/25419218-2019-06-08
7 Urakov A.L. Thermal pharmacology: history and definition. Reviews on Clinical Pharmacology and Drug Therapy. 2021;19(1):87-96 (In Russ.). DOI: 10.17816/RCF19187-96

8 Urakov A.L., Yagudin I.I., Suntsova D.O., Svetova M.D., Stolyarenko A.P. COVID-19: thick pus, mucus and sputum with streaks of blood as a cause of airway obturation in SARS and oxygen-foaming pus solvent as a medicine for their recanalization. Acta Scientific Women's Health. 2021;3(5):75-7.

9 Strelkov N.S., Urakov A.L., Korovyakov A.P., Urakova N.A., et al. A method of treating long-term non-healing wounds. RU patent 2187287. 2002 Aug 20. 